\section{Kidney \\ Blood Pressure Research}

\title{
NOS3 894G > T Polymorphism is Associated With Progression of Kidney Disease and Cardiovascular Morbidity in Type 2 Diabetic Patients: NOS3 as a Modifier Gene for Diabetic Nephropathy?
}

\author{
Katarína Kuricováa,c Veronika Tanhäuserováa,c Lukáš Pácala Vendula Bartákováa \\ Lucie Brožováb Jiř́ Jarkovskýb Kateřina Kaňkováa
}

aDepartment of Pathophysiology, Faculty of Medicine, Masaryk University; ${ }^{b}$ Institute of Biostatistics and Analyses, Masaryk University, Brno, Czech Republic; 'Both authors contributed equally to this work

\section{Key Words}

Diabetic nephropathy $•$ Nitric oxide synthase $\cdot$ Polymorphism • Cardiovascular morbidity

\begin{abstract}
Background/Aims: We have previously associated SNP 894G>T in the NOS3 gene with diabetic nephropathy (DN) using multi-locus analysis. Variant $894 \mathrm{G}>$ T has been widely studied as a DN susceptibility factor with contradictory results. In the present study we genotyped $894 \mathrm{G}>\mathrm{T}$ in the cohort of prospectively followed type 2 diabetics with the aim to investigate its possible role in the progression of DN and development of morbidity and mortality associated with diabetes. Methods: 311 subjects with defined stage of DN were enrolled in the study and followed up for a median of 38 months. We considered three end-points: progression of DN, major cardiovascular event and all-cause mortality. Results: Considering baseline GFR, age at enrolment and diabetes duration as confounders, Cox regression analysis identified 894GT genotype as a risk factor for $\mathrm{DN}$ progression ( $\mathrm{HR}=1.843[95 \% \mathrm{CI} 1.088-3.119], \mathrm{P}=0.023)$ and 894TT genotype as a risk factor for major cardiovascular event (HR $=2.515$ [95\% CI 1.060 - 5.965], $P=0.036$ ). Conclusion: We ascertained the significant effect of the NOS3 894G>T variant on DN progression and occurrence of major cardiovascular event in T2DM subjects. Based on these results NOS3 can be considered a modifier gene for DN.
\end{abstract}

Copyright $\odot 2014$ S. Karger AG, Basel

\section{Introduction}

Chronic hyperglycaemia accompanying diabetes is responsible for the development of diabetes-specific microvascular pathologies of which diabetic nephropathy (DN) is a 


\section{Kidney Blood Pressure Research}

Kidney Blood Press Res 2013;38:92-98

\begin{tabular}{l|l}
\hline DOI: 10.1159/000355757 & $\begin{array}{l}\text { C 2014 S. Karger AG, Basel } \\
\text { www.karger.com/kbr }\end{array}$ \\
Published onlIne: February 26, 2014 &
\end{tabular}

Published onlıne: February 26, 2014

common and serious complication of diabetes since, at certain point, renal function starts declining, i.e. chronic kidney disease (CKD) eventually progresses to the end-stage renal disease (ESRD). Both diabetes itself and associated CKD increase cardiovascular morbidity and mortality making diabetes one of the most common causes of death worldwide [1].

Contribution of genetic factors to the development of DN has been soundly established. The evidence was initially provided by studies showing familial clustering [2-4], differences between ethnic groups [5] and segregation analyses [6,7]. Subsequently, numerous genetic association studies were carried out, typically using candidate gene approach and focusing on a single gene at the time. Before the onset of genome-wide association studies (GWAS) we attempted to take into account likely polygenic pattern of DN genetic susceptibility and employed the multi-locus approach using the set-association analysis in a case - control study comprising 419 type 2 diabetics and 228 healthy subjects genotyped for 45 single nucleotide polymorphisms (SNPs) in 20 candidate genes for DN [8]. Using such approach we identified SNPs in four genes - AGER, EDN1 and LTA on chromosome 6p and NOS3 on chromosome $7 \mathrm{q}$ - associated with DN in type 2 diabetes (T2DM).

So far only few GWAS in DN were performed. The first one, performed on a Japanese population with type 1 diabetes mellitus (T1DM), identified association of SNP in SLC12A3 with DN [9]. Next GWAS performed on Pima Indians with T2DM revealed PVT1 as a susceptibility gene for ESRD in diabetes [10]. Results of the first GWAS in T1DM subjects with European descent have been published in 2009 [11]. The study identified SNPs in several genes as possibly contributing to ESRD susceptibility however these associations did not reach genome-wide significance. Another study on European T1DM population found association of SNPs in FRMD3 and CARS with DN [12]. First GWAS in African Americans with T2DM identified several SNPs as potential candidates, however, genome-wide significance has not been reached [13]. Recently, a large meta-analysis of GWAS of DN in T1DM detected association of the three new SNPs with ESRD and DN [14]. Altogether, results of currently available GWAS are inconsistent with only several SNPs associated with DN susceptibility (and typically not shared by different populations or diabetes types).

Endothelial isoform of the nitric oxide synthase, encoded by NOS3 catalysing production of nitric oxide is involved in the regulation of vascular tone and large body of data supports its role in the pathogenesis of DN [15]. Due to the above mentioned (pathogenically plausible) association of the NOS3 with DN we were interested whether our previous finding of association with the susceptibility to DN using cross-sectional study design could be extended to its role in the modulation of DN progression, i.e. the role of the NOS3 as a modifier gene. Therefore, the aim of the study was to replicate genotyping of NOS3 894G>T SNP in an independent cohort of prospectively followed T2DM subjects with variable stage of DN at baseline to ascertain its possible predictive potential for the progression of DN (primary outcome), cardiovascular morbidity and mortality and all-cause mortality (secondary outcomes).

\section{Materials and Methods}

\section{Subjects}

A total of 311 consecutive unrelated T2DM subjects (157 men and 154 women) with variable stage of kidney damage followed in Diabetes and Nephrology units of the two University hospitals in Brno, Czech Republic were enrolled into the study between 2002 and 2007. Prospective data were collected until the end of 2011. The stage of DN was defined according to the urinary albumin excretion (UAE). At baseline our study sample consisted of: normoalbuminuric subjects (UAE $<30 \mathrm{mg} / 24 \mathrm{~h}, 9.6 \%$ ), microalbuminuric subjects (UAE 30-300 mg/24 h, $35.7 \%$ ), macroalbuminuric subjects (UAE > $300 \mathrm{mg} / 24 \mathrm{~h}, 42.1 \%$ ) and subject with end-stage renal disease (ESRD, $=$ CKD V, $12.6 \%$ ) for whom UAE was not ascertained. Stage of CKD was determined by glomerular filtration rate (GFR) assessed by creatinine clearance based on $24 \mathrm{~h}$ urine collection. Respective staging for CKD in the same sample was: CKD I (GFR $\geq 90 \mathrm{ml} / \mathrm{min}$ per $1.73 \mathrm{~m}^{2}$, $19.6 \%$ ), CKD II (60-89 ml/min per $1.73 \mathrm{~m}^{2}, 18.2 \%$ ), CKD III (30-59 ml/min per $1.73 \mathrm{~m}^{2}, 32.3 \%$ ), CKD IV 


\section{Kidney \\ Blood Pressure Research}

\begin{tabular}{l|l}
\hline \multicolumn{2}{|l}{ Kidney Blood Press Res 2013;38:92-98 } \\
\hline DOI: 10.1159/000355757 & $\begin{array}{l}\text { (c) 2014 S. Karger AG, Basel } \\
\text { www.karger.com/kbr }\end{array}$ \\
Published onlIne: February 26, 2014 &
\end{tabular}

Kuricová/Tanhäuserová/Pácal/Bartáková/Brožová/Jarkovský/Kaňková: NOS3 894G>T polymorphism and progression of kidney disease and cardiovascular morbidity

Table 1. Baseline demographic and clinical characteristics of the subjects

\begin{tabular}{lccccc}
\hline Parameter (unit) & $\begin{array}{c}\text { Normoalbuminuria } \\
(\mathrm{n}=30)\end{array}$ & $\begin{array}{c}\text { Microalbuminuria } \\
(\mathrm{n}=111)\end{array}$ & $\begin{array}{c}\text { Macroalbuminuria } \\
(\mathrm{n}=131)\end{array}$ & $\begin{array}{c}\text { ESRD } \\
(\mathrm{n}=39)\end{array}$ & $\mathrm{P}$ \\
\hline Age (years) & $64[59-72]$ & $68[57-75]$ & $67[61-74]$ & $72[62-78]$ & $\mathrm{NS}$ \\
Duration of diabetes (years) & $13[8-16]$ & $10[6-18]$ & $16[8-21]$ & $17[14-22]$ & 0.002 \\
FPG (mmol/l) & $7.7[6.2-10.0]$ & $8.1[7.2-11.2]$ & $8.9[7.0-11.1]$ & $8.4[6.2-10.2]$ & $\mathrm{NS}$ \\
HbA1c $(\%)$ & $6.4[5.2-7.5]$ & $6.5[5.3-8.1]$ & $7.7[5.7-8.8]$ & $6.2[5.2-7.2]$ & $\mathrm{NS}$ \\
Triglycerides (mmol/l) & $1.9[1.4-2.8]$ & $2.0[1.4-3.0]$ & $2.1[1.5-3.5]$ & $2.0[1.6-2.5]$ & $\mathrm{NS}$ \\
Total cholesterol $(\mathrm{mmol} / \mathrm{l})$ & $5.0[4.3-6.2]$ & $4.9[4.3-5.7]$ & $5.1[4.3-6.1]$ & $4.5[3.6-5.4]$ & 0.027 \\
Creatinine $(\mu \mathrm{mol} / \mathrm{l})$ & $88[81-105]$ & $115[91-153]$ & $162[123-237]$ & $524[462-632]$ & $<0.001$ \\
Proteinuria $(\mathrm{g} / 24 \mathrm{~h})$ & $0.11[0.09-0.12]$ & $0.13[0.08-0.21]$ & $1.55[0.60-3.25]$ & - & $<0.001$ \\
GFR $\left(\mathrm{m} / \mathrm{min}\right.$ per $\left.1.73 \mathrm{~m}^{2}\right)$ & $95.5[79.3-138.0]$ & $57.5[41.6-86.0]$ & $45.4[29.4-70.1]$ & - & $<0.001$ \\
UAE (mg/24 h) & $11[8-13]$ & $60[26-160]$ & $404[111-752]$ & - & $<0.001$ \\
\hline
\end{tabular}

Data are expressed as median [interquartile range]. Comparisons made by Kruskal-Wallis ANOVA.

Abbreviations: ESRD, end stage renal disease; FPG, fasting plasma glucose; GFR, glomerular filtration rate; $\mathrm{HbA}_{1 \mathrm{c}}$, glycated haemoglobin; UAE, urinary albumin excretion

$\left(15-29 \mathrm{ml} / \mathrm{min}\right.$ per $\left.1.73 \mathrm{~m}^{2}, 13.4 \%\right)$ and subjects with CKD V at baseline (GFR $<15 \mathrm{ml} / \mathrm{min}$ per $1.73 \mathrm{~m}^{2}$ or maintenance haemodialysis, $16.5 \%$ ). Both parameters - UAE and GFR - were repeatedly measured at least once in 6 months or more often, staging for DN and CKD was based on two consecutive values. Retinopathy at baseline was confirmed in $35.8 \%$ of subject and neuropathy in $28.4 \%$. Treatment of diabetes consisted of oral anti-diabetic drugs (52.3\% of subjects) and insulin (55.4\%), renoprotective treatment of angiotensinconverting enzyme inhibitors (63.5\%) and angiotensin II type 2 receptor blockers (42.2\%). Clinical characteristics of patients are shown in Table 1. All subjects originated from the South Moravia region of Czech Republic and all were of the Caucasian origin. Informed consent was obtained from each patient prior to being included in the study. The study was performed in accordance with principles of the Declaration of Helsinki and approved by the Ethical committee of the Faculty of Medicine, Masaryk University Brno.

\section{Follow-up data}

Subjects were followed for a median of 38 [21 - 65] months. Three end-points were considered: (i) progression of DN (i.e. transition from any given baseline DN stage except of ESRD at baseline to a more advanced stage of albuminuria/proteinuria or to ESRD), (ii) major cardiovascular event (non-fatal or fatal myocardial infarction or stroke, limb amputation, revascularisation) and (iii) all-cause mortality. In case of the assessment of the progression of DN (primary outcome), patients with ESRD at baseline $(n=39)$ were excluded from this analysis since they could not progress further.

\section{Detection of polymorphism}

Sample of peripheral venous blood was taken from each subject at the time of enrolment in the study. DNA was extracted from separated peripheral blood leukocytes by the phenol-chloroform method and stored at $-20^{\circ} \mathrm{C}$ until further analysis. NOS3 894G $>$ T (E298D, rs1799983) SNP was detected using polymerase chain reaction with subsequent restriction analysis as described previously [16].

\section{Statistical analysis}

Differences in variables between the groups were analysed using Kruskal-Wallis ANOVA, observed vs. expected frequencies tested by chi-square test. Univariate Cox regression analysis was used for detection of possible confounding factors. Cox proportional model adjusted for confounders was used to evaluate hazard ratios for NOS3 SNP. For all standard analysis Statistica for Windows (Statsoft Inc., Tulsa, OK, USA) was used. $\mathrm{P} \leq 0.05$ was considered statistically significant.

\section{Results}

At the end of the follow-up period, the cumulative incidence of DN progression reached $26.5 \%(\mathrm{n}=272)$, in particular $4.2 \%$ progressed from normo- to microalbuminuria, $1.4 \%$ 


\section{Kidney Blood Pressure Research}

Kidney Blood Press Res 2013;38:92-98

DOI: 10.1159/000355757

Published onlıne: February 26, 2014

C 2014 S. Karger AG, Base

www.karger.com/kbr

Kuricová/Tanhäuserová/Pácal/Bartáková/Brožová/Jarkovský/Kaňková: NOS3 894G>T polymorphism and progression of kidney disease and cardiovascular morbidity

Table 2. Results of univariate Cox regression analysis

\begin{tabular}{|c|c|c|c|c|c|c|}
\hline \multirow{2}{*}{ Parameter } & \multicolumn{2}{|c|}{ DN progression } & \multicolumn{2}{|c|}{ Major cardiovascular event } & \multicolumn{2}{|c|}{ All-cause mortality } \\
\hline & $\mathrm{HR}(95 \% \mathrm{CI})$ & $\mathrm{P}$ & $\operatorname{HR}(95 \% \mathrm{CI})$ & $\mathrm{P}$ & HR $(95 \% \mathrm{CI})$ & $\mathrm{P}$ \\
\hline Age at enrolment & $1.005(0.984-1.026)$ & NS & $1.028(1.005-1.052)$ & 0.017 & $1.045(1.022-1.068)$ & $<0.001$ \\
\hline Sex (men) & $0.724(0.452-1.161)$ & NS & $1.101(0.668-1.813)$ & NS & $0.917(0.580-1.450)$ & NS \\
\hline Duration of diabetes & $1.025(0.999-1.051)$ & NS & $1.045(1.018-1.072)$ & 0.001 & $1.046(1.021-1.072)$ & $<0.001$ \\
\hline BMI & $0.993(0.953-1.034)$ & NS & $0.967(0.919-1.017)$ & NS & $0.962(0.918-1.009)$ & NS \\
\hline SBP & $1.003(0.988-1.017)$ & NS & $0.999(0.984-1.014)$ & NS & $1.002(0.988-1.017)$ & NS \\
\hline DBP & $0.988(0.962-1.015)$ & NS & $0.975(0.947-1.003)$ & NS & $0.971(0.944-0.998)$ & 0.034 \\
\hline GFR & $0.148(0.074-0.296)$ & $<0.001$ & $0.158(0.070-0.354)$ & $<0.001$ & $0.136(0.060-0.306)$ & $<0.001$ \\
\hline $\mathrm{HbA}_{1 \mathrm{c}}$ & $0.977(0.820-1.165)$ & NS & $0.972(0.818-1.154)$ & NS & $0.919(0.778-1.085)$ & NS \\
\hline
\end{tabular}

from normo- to macroalbuminuria, $31.9 \%$ from micro- to macroalbuminuria, $15.3 \%$ from microalbuminuria to ESRD and $47.2 \%$ from macroalbuminuria to ESRD. Cardiovascular event was reached in $19.9 \%$ of subjects from whom $48.4 \%$ had non-fatal cardiovascular event and $61.3 \%$ had fatal cardiovascular event. Of those with fatal cardiovascular event $15.8 \%$ had a non-fatal cardiovascular event followed by fatal cardiovascular event during the follow-up period, for the purpose of the analysis however only the first, earlier one was considered. Cumulative incidence of all-cause mortality was $23.8 \%$.

Overall SNP genotyping success rate was $100 \%$. Genotype frequencies were $49.8 \%$ GG, $40.3 \%$ GT and $9.9 \%$ TT, Hardy-Weinberg equilibrium was not violated (P = NS, chisquare test). In order to reveal possible non-genetic confounders we applied univariate Cox regression analysis (Table 2). GFR was identified as a confounder of DN progression ( $\mathrm{P}<$ 0.001). Age at enrolment $(P=0.017)$, diabetes duration $(P=0.001)$ and GFR $(P<0.001)$ were found as confounders of major cardiovascular event and all-cause mortality ( $\mathrm{P}<0.001$ for age; $\mathrm{P}<0.001$ for diabetes duration and $\mathrm{P}<0.001$ for GFR). Cox regression analysis of DN progression $(n=272)$ adjusted for age, diabetes duration and GFR demonstrated GT genotype as a predictor of DN progression (hazard ratio (HR) 1.843 [95\% CI $1.088-3.119], \mathrm{P}=0.023$ ). The dominant model (i.e. genotypes containing minor allele were grouped together and compared to remaining homozygote) generated negative result $(\mathrm{P}>0.05)$. Using the same approach, genotype TT was identified as a risk factor for major cardiovascular event (HR = 2.515 [95 \% CI $1.060-5.965], P=0.036$ ) and again no difference was found in a dominant model $(\mathrm{P}>0.05)$. Finally, no significant contribution of the NOS3 $894 \mathrm{G}>\mathrm{T}$ genotypes to allcause mortality was ascertained $(\mathrm{P}>0.05)$.

\section{Discussion}

In the present study, we identified genetic variant $894 \mathrm{G}>\mathrm{T}$ in the NOS3 gene as a risk factor for the progression of DN in T2DM, therefore, we ascertained the role of NOS3 as a modifier gene for the clinical course of DN. Furthermore, NOS3 894G $>$ T was identified as a risk factor for the major cardiovascular event in T2DM patients. Numerous SNPs in the NOS3 have been described, some of them associated with various diseases such as hypertension and coronary artery disease $[17,18]$ and - in case of $894 \mathrm{G}>\mathrm{T}$ - with susceptibility to DN in our previous study [8]. A number of studies (of various sample size, ethnicity and inclusion criteria though) reported conflicting results regarding the relationship between NOS3 894G $>$ T SNP and susceptibility to diabetic complications incl. DN. Several meta-analyses of case-control studies were performed so far on the NOS3 894G>T in DN. Chronologically, 


\section{Kidney Blood Pressure Research}

Kidney Blood Press Res 2013;38:92-98

\begin{tabular}{l|l}
\hline DOI: $10.1159 / 000355757$ & C 2014 S. Karger AG, Basel
\end{tabular}

Published onlıne: February 26, 2014

www.karger.com/kbr

Kuricová/Tanhäuserová/Pácal/Bartáková/Brožová/Jarkovský/Kaňková: NOS3 894G>T polymorphism and progression of kidney disease and cardiovascular morbidity

the first and only one so far [19] that stratified for diabetes type have shown association of $894 \mathrm{G}>\mathrm{T}$ with DN in Caucasians with T2DM. Other two meta-analyses focusing on NOS3 $894 \mathrm{G}>\mathrm{T}$ variant in DN in several populations identified $894 \mathrm{G}>\mathrm{T}$ variant as a risk factor for DN in Asian but not Caucasian populations [20,21]. Recent meta-analysis analysed association of the 894G>T variant with ESRD and found the T allele associated with ESRD susceptibility in overall population (including Caucasian, Asian, Brazil and African populations) and in Asians but not Caucasians separately [22].

Number of studies previously investigated functional impact of the NOS3 894G>T missense polymorphism. Experimental in vitro data indicated that amino acid change generates protein with higher susceptibility to cleavage with subsequent functional effect [23]. Furthermore, NO production was significantly lower in stably transfected CHO 894T cells [24]. Additionally, diabetic carriers of the 894T allele exhibited significantly lower serum NO levels [25]. However, other studies, on the contrary, did not find any functional effect of this SNP [26, 27]. We have to nevertheless bear in mind that NOS3 894G>T might be a mere marker of another linked functional variant, therefore, the proof of functionality is not automatically proof of causality. What is more important in the context of the current study is that functional consequences of the NOS3 genetic variability might not only affect the onset of DN but - due to the complex role of eNOS/NO axis in the regulation of renal haemodynamic - also modulate its clinical course and severity. The role of NOS3 as a modifier gene has only been studied in limited extent in renal pathology so far (only in the polycystic kidney disease $[28,29])$. To our knowledge this is the first attempt to analyse NOS3 as a modifier gene in DN and we ascertained statistically significant effect of the $894 \mathrm{G}>\mathrm{T}$ on the progression of DN.

The studied SNP was also significantly associated with the occurrence of the major cardiovascular event in T2DM subjects. Possible link between NOS3 894G>T and cardiovascular morbidity and mortality has been widely studied, unfortunately, most studies published so far were performed on non-Caucasian populations. Four recent meta-analyses found association of NOS3 SNP with ischemic stroke [30-32] or coronary heart disease [33] in Asian populations. No such association was found for Caucasian population. SNP 894G $>$ T was also associated with susceptibility to cardiovascular disease normoalbuminuric type 1 diabetic subjects [34].

\section{Conclusion}

Using the prospective cohort of precisely clinically characterised T2DM subjects we demonstrated association of NOS3 variant $894 \mathrm{G}>\mathrm{T}$ with DN progression and major cardiovascular event. NOS3 gene can be considered modifier gene for DN, however, replication studies and more comprehensive genetic characterisation are warranted.

\section{Conflict of Interests}

None declared.

\section{Acknowledgements}

Study was supported by the grant NT11405 from the Ministry of Health of Czech Republic. Authors wish to thank Jitka Řehořová and Jana Bělobrádková, Dept. of Internal Medicine, University Hospital Brno, Czech Republic and Jan Svojanovský and Jindřich Olšovský, $2^{\text {nd }}$ Dept. of Internal Medicine, St. Anne's University Hospital, Brno, Czech Republic for the enrolment of study subjects and collection of relevant clinical data during the followup. 


\section{Kidney \\ Blood Pressure Research}

Kidney Blood Press Res 2013;38:92-98

DOI: $10.1159 / 000355757$

Published onlıne: February 26, 2014

(C) 2014 S. Karger AG, Basel

www.karger.com/kbr

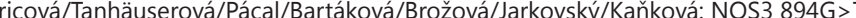
polymorphism and progression of kidney disease and cardiovascular morbidity

\section{References}

$\checkmark 1$ Ma RCW, Tong PCY: Epidemiology of Type 2 Diabetes; in Holt RIG, Cockram CS, Flyvbjerg A, Goldstein BJ (eds): Textbook of Diabetes, Oxford, Wiley-Blackwell, 2010, pp 45 - 68.

-2 Quinn M, Angelico MC, Warram JH, Krolewski AS: Familial factors determine the development of diabetic nephropathy in patients with iddm. Diabetologia 1996;39:940-945.

-3 Pettitt DJ, Saad MF, Bennett PH, Nelson RG, Knowler WC: Familial predisposition to renal disease in two generations of pima indians with type 2 (non-insulin-dependent) diabetes mellitus. Diabetologia 1990;33:438-443.

4 Seaquist ER, Goetz FC, Rich S, Barbosa J: Familial clustering of diabetic kidney disease. Evidence for genetic susceptibility to diabetic nephropathy. N Engl J Med 1989;320:1161-1165.

5 Chandie Shaw PK, Baboe F, van Es LA, van der Vijver JC, van de Ree MA, de Jonge N, Rabelink TJ: Southasian type 2 diabetic patients have higher incidence and faster progression of renal disease compared with dutch-european diabetic patients. Diabetes Care 2006;29:1383-1385.

6 Berger M, Monks D, Wanner C, Lindner TH: Diabetic nephropathy: An inherited disease or just a diabetic complication? Kidney Blood Press Res 2003;26:143-154.

7 Thomas MC, Groop PH, Tryggvason K: Towards understanding the inherited susceptibility for nephropathy in diabetes. Curr Opin Nephrol Hypertens 2012;21:195-202.

8 Kankova K, Stejskalova A, Pacal L, Tschoplova S, Hertlova M, Krusova D, Izakovicova-Holla L, Beranek M, Vasku A, Barral S, Ott J: Genetic risk factors for diabetic nephropathy on chromosomes 6p and 7q identified by the set-association approach. Diabetologia 2007;50:990-999.

-9 Tanaka N, Babazono T, Saito S, Sekine A, Tsunoda T, Haneda M, Tanaka Y, Fujioka T, Kaku K, Kawamori R, Kikkawa R, Iwamoto Y, Nakamura Y, Maeda S: Association of solute carrier family 12 (sodium/ chloride) member 3 with diabetic nephropathy, identified by genome-wide analyses of single nucleotide polymorphisms. Diabetes 2003;52:2848-2853.

-10 Hanson RL, Craig DW, Millis MP, Yeatts KA, Kobes S, Pearson JV, Lee AM, Knowler WC, Nelson RG, Wolford JK: Identification of pvt1 as a candidate gene for end-stage renal disease in type 2 diabetes using a poolingbased genome-wide single nucleotide polymorphism association study. Diabetes 2007;56:975-983.

11 Craig DW, Millis MP, DiStefano JK: Genome-wide snp genotyping study using pooled DNA to identify candidate markers mediating susceptibility to end-stage renal disease attributed to type 1 diabetes. Diabet Med 2009;26:1090-1098.

12 Pezzolesi MG, Poznik GD, Mychaleckyj JC, Paterson AD, Barati MT, Klein JB, Ng DP, Placha G, Canani LH, Bochenski J, Waggott D, Merchant ML, Krolewski B, Mirea L, Wanic K, Katavetin P, Kure M, Wolkow P, Dunn JS, Smiles A, Walker WH, Boright AP, Bull SB, Doria A, Rogus JJ, Rich SS, Warram JH, Krolewski AS: Genome-wide association scan for diabetic nephropathy susceptibility genes in type 1 diabetes. Diabetes 2009;58:1403-1410.

13 McDonough CW, Palmer ND, Hicks PJ, Roh BH, An SS, Cooke JN, Hester JM, Wing MR, Bostrom MA, Rudock ME, Lewis JP, Talbert ME, Blevins RA, Lu L, Ng MC, Sale MM, Divers J, Langefeld CD, Freedman BI, Bowden DW: A genome-wide association study for diabetic nephropathy genes in african americans. Kidney Int 2011;79:563-572.

14 Sandholm N, Salem RM, McKnight AJ, Brennan EP, Forsblom C, Isakova T, McKay GJ, Williams WW, Sadlier DM, Makinen VP, Swan EJ, Palmer C, Boright AP, Ahlqvist E, Deshmukh HA, Keller BJ, Huang H, Ahola AJ, Fagerholm E, Gordin D, Harjutsalo V, He B, Heikkila O, Hietala K, Kyto J, Lahermo P, Lehto M, Lithovius R, Osterholm AM, Parkkonen M, Pitkaniemi J, Rosengard-Barlund M, Saraheimo M, Sarti C, Soderlund J, SoroPaavonen A, Syreeni A, Thorn LM, Tikkanen H, Tolonen N, Tryggvason K, Tuomilehto J, Waden J, Gill GV, Prior S, Guiducci C, Mirel DB, Taylor A, Hosseini SM, Parving HH, Rossing P, Tarnow L, Ladenvall C, AlhencGelas F, Lefebvre P, Rigalleau V, Roussel R, Tregouet DA, Maestroni A, Maestroni S, Falhammar H, Gu T, Mollsten A, Cimponeriu D, Ioana M, Mota M, Mota E, Serafinceanu C, Stavarachi M, Hanson RL, Nelson RG, Kretzler M, Colhoun HM, Panduru NM, Gu HF, Brismar K, Zerbini G, Hadjadj S, Marre M, Groop L, Lajer M, Bull SB, Waggott D, Paterson AD, Savage DA, Bain SC, Martin F, Hirschhorn JN, Godson C, Florez JC, Groop PH, Maxwell AP: New susceptibility loci associated with kidney disease in type 1 diabetes. PLoS Genet 2012;8:e1002921.

15 Baylis C: Nitric oxide synthase derangements and hypertension in kidney disease. Curr Opin Nephrol Hypertens 2012;21:1-6. 


\section{Kidney \\ Blood Pressure Research}

Kidney Blood Press Res 2013;38:92-98

DOI: 10.1159/000355757

Published onlıne: February 26, 2014

(C) 2014 S. Karger AG, Basel

www.karger.com/kbr

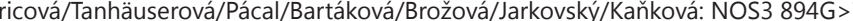
polymorphism and progression of kidney disease and cardiovascular morbidity

16 Novoradovsky A, Brantly ML, Waclawiw MA, Chaudhary PP, Ihara H, Qi L, Eissa NT, Barnes PM, Gabriele KM, Ehrmantraut ME, Rogliani P, Moss J: Endothelial nitric oxide synthase as a potential susceptibility gene in the pathogenesis of emphysema in alpha1-antitrypsin deficiency. Am J Respir Cell Mol Biol 1999;20:441447.

17 Misono M, Maeda S, Iemitsu M, Nakata Y, Otsuki T, Sugawara J, Zempo H, Yoshizawa M, Miyaki A, Kuno S, Matsuda M, Ajisaka R: Combination of polymorphisms in the beta2-adrenergic receptor and nitric oxide synthase 3 genes increases the risk for hypertension. J Hypertens 2009;27:1377-1383.

18 Han Y, Xu W, Zhang W, Liu N, Ji Y: T-786c polymorphism in the endothelial nitric oxide synthase gene is associated with increased risk of coronary artery disease in a chinese population. Pharmacology 2010;85:211-216.

19 Zintzaras E, Papathanasiou AA, Stefanidis I: Endothelial nitric oxide synthase gene polymorphisms and diabetic nephropathy: A huge review and meta-analysis. Genet Med 2009;11:695-706.

20 He Y, Fan Z, Zhang J, Zhang Q, Zheng M, Li Y, Zhang D, Gu S, Yang H: Polymorphisms of enos gene are associated with diabetic nephropathy: A meta-analysis. Mutagenesis 2011;26:339-349.

21 Zeng Z, Li L, Zhang Z, Li Y, Wei Z, Huang K, He L, Shi Y: A meta-analysis of three polymorphisms in the endothelial nitric oxide synthase gene (nos3) and their effect on the risk of diabetic nephropathy. Hum Genet 2010;127:373-381.

-22 Zhou TB, Xu HL, Yin SS: Association between endothelial nitric oxide synthase glu298asp gene polymorphism and diabetic nephropathy susceptibility. Ren Fail 2013;35:173-178.

23 Tesauro M, Thompson WC, Rogliani P, Qi L, Chaudhary PP, Moss J: Intracellular processing of endothelial nitric oxide synthase isoforms associated with differences in severity of cardiopulmonary diseases: Cleavage of proteins with aspartate vs. Glutamate at position 298. Proc Natl Acad Sci U S A 2000;97:28322835.

24 Noiri E, Satoh H, Taguchi J, Brodsky SV, Nakao A, Ogawa Y, Nishijima S, Yokomizo T, Tokunaga K, Fujita T: Association of enos glu298asp polymorphism with end-stage renal disease. Hypertension 2002;40:535540.

-25 Ahluwalia TS, Ahuja M, Rai TS, Kohli HS, Sud K, Bhansali A, Khullar M: Endothelial nitric oxide synthase gene haplotypes and diabetic nephropathy among asian indians. Mol Cell Biochem 2008;314:9-17.

26 Fairchild TA, Fulton D, Fontana JT, Gratton JP, McCabe TJ, Sessa WC: Acidic hydrolysis as a mechanism for the cleavage of the glu(298)-->asp variant of human endothelial nitric-oxide synthase. J Biol Chem 2001;276:26674-26679.

27 Ritt M, Ott C, Delles C, Schneider MP, Schmieder RE: Impact of the endothelial nitric oxide synthase gene g894t polymorphism on renal endothelial function in patients with type 2 diabetes. Pharmacogenet Genomics 2008;18:699-707.

28 Persu A, Stoenoiu MS, Messiaen T, Davila S, Robino C, El-Khattabi O, Mourad M, Horie S, Feron O, Balligand JL, Wattiez R, Pirson Y, Chauveau D, Lens XM, Devuyst O: Modifier effect of enos in autosomal dominant polycystic kidney disease. Hum Mol Genet 2002;11:229-241.

29 Stefanakis N, Ziroyiannis P, Trygonis S, Lamnissou K: Modifier effect of the glu298asp polymorphism of endothelial nitric oxide synthase gene in autosomal-dominant polycystic kidney disease. Nephron Clin Pract 2008;110:c101-106.

-30 Niu PP, Yang G, Zheng BK, Guo ZN, Jin H, Yang Y: Relationship between endothelial nitric oxide synthase gene polymorphisms and ischemic stroke: A meta-analysis. Acta Neurol Scand 2013;128:202-212.

-31 Yao YS, Chang WW, Jin YL, He LP: An updated meta-analysis of endothelial nitric oxide synthase gene: Three well-characterized polymorphisms with ischemic stroke. Gene 2013;528:84-92.

-32 Wang M, Jiang X, Wu W, Zhang D: Endothelial no synthase gene polymorphisms and risk of ischemic stroke in asian population: A meta-analysis. PLoS One 2013;8:e60472.

33 Tian GX, Zeng XT, Wang XB, Zhang L, Zhang W, Wei WL: Association between the endothelial nitric oxide synthase gene glu298asp polymorphism and coronary heart disease: A metaanalysis of 39 casecontrol studies. Mol Med Rep 2013;7:1310-1318.

-34 Mollsten A, Lajer M, Jorsal A, Tarnow L: The endothelial nitric oxide synthase gene and risk of diabetic nephropathy and development of cardiovascular disease in type 1 diabetes. Mol Genet Metab 2009;97:8084. 